\title{
POLICE RECONSTRUCTION POLICY AND LAW IN THE IMPLEMENTATION OF ATTORNEY RESTORATIVE JUSTICE EMBEZZLEMENT BASED CRIME LAW PROGRESSIVE
}

\author{
Sulistyowati \\ Lecturer in Faculty of Law, Muria Kudus University \\ Email : Sulistyowati@umk.ac.id
}

\begin{abstract}
The aim of this study is to determine and assess the legal policy in the Police and the Prosecutor in the application of restorative justice criminal offense of embezzlement today, to know and study the the obstacles of legal policy in the Police and the Prosecutor in the application of restorative justice acts criminal embezzlement based on Progressive Law. This research is descriptive analytic research, which means the results of this study seeks to provide a thorough and in-depth description of a situation, fact or phenomenon. Approach method used in this study was empirical juridical approach or Socio - Legal Research. Analysis data used in this research was a qualitative descriptive data analysis. Results of this study are (1) The policy of law on the Police and the Prosecutor in the application of restorative justice criminal offense of embezzlement is for the investigation of the offenses of embezzlement. The investigators still examine the perpetrators, victims and witnesses, as well as what happens at the level of the prosecution attorney. The attorneys as a public prosecutor still proceed with the prosecution in accordance with the criminal procedure. Justice system if the parties so good Perpetrators, agreed to make peace and do not want to continue the case to the next process, the Investigator Police will apply discretion by allowing the case file was hanging in the sense of not issued Warrant Termination of Investigation but did not proceed to the extent prosecution. Also at the level of prosecution, as the Attorney General Prosecutor not issued Cessation prosecution but also does not proceed bestow the file to the Court; (2) Factors to be obstacles in the implementation of legal policies Police and the Attorney General in the implementation of restorative justice criminal offense of embezzlement at this time.
\end{abstract}

Keywords : Policy Reconstruction Law, Restorative Justice, Progressive Law.

\section{A. INTRODUCTION}

Human is as personal being completed with all kinds of personal types and uniqueness of personality. They are also as social beingswho always depend on and relate to each other. Reliance and relationships are usually based on a mutual need or a symbiotic mutualism. However, along with the time and the changing of intentions and movements, it is likely to shift from mutually beneficial relations to the disadvantaged. This will change the qualifications of the Civil Code behavior to shift to the Legal Acts Criminal. In relation to the foregoing matters, juridical, a legal relationship conducted by a person with another person who was originally very civic or individual contract, along with the emergence of fact violation of law can develop into a complex problem because there is a fact of criminal law dimension. Facts of civil law, such as legal events in the form of Working Agreement Letter of business capital, leases, borrowing, because one party is treasonous and does not keep promises and there is bad faith to control goods or money by way of against the rights or against the law and harm the material of others. Thus, there will be a criminal case either in the form of embezzlement or at the same time embezzlement and fraud.

In case of embezzlement, one of the parties has a material loss, and the aggrieved 
party (hereinafter referred to as the Victim of Embezzlement) certainly wishes that the loss could be eliminated if the embezzler (hereinafter referred to as the criminal) would return the goods or money. Actually the problem is simple, the criminal can aware that the goods or money is not his either partially or wholly. The shifting of Civil Relationship as described above in the course of time that can be metamorphosed into a Criminal problem. Since, there are facts as a criminal action qualification in the form of embezzlement. The criminal act of embezzlement, in the Criminal Code is set out in Section II of Chapter XXIV, starting with Articles 372 up to Article 377 of the Criminal Code. The subject of the embezzlement article is contained in Article 372 of the Criminal Code which reads as follows: "Whosoever intentionally and unlawfully owns the goods wholly or partly belongs to another, but who is in his power not because the crime is threatened by embezzlement, by the maximum imprisonment For four years or a fine of not more than nine hundred rupiah. "

Based on the type, the criminal act of embezzlement is classified into 4 (four) things, namely: 1) Ordinary Embezzlement: that is embezzlement as intended and has been regulated in the provisions of Article 372 of the Criminal Code, as written in on; 2) Mild Evasion: that is embezzlement if the goods that have been embezzled are not cattle and the price is not more than twenty five thousand rupiah, as intended and has been regulated in the provisions of Article 373 of the Criminal Code; 3) Embezzlement With Objection: ie embezzlement done by the person holding the goods in connection with his occupation or his position or because he is paid, this is in accordance with the provisions referred to in Article 374 of the Criminal Code; 4) Embezzlement in the Family Environment: is embezzlement done by a person who, having been given goods to be stored, or by a guardian, administrator, executor or executor of a will, a social institution or foundation, of a thing under his control, is in accordance with the provisions Which is written in Article 375 of the Criminal Code.

The provision of Article 372 of the Criminal Code as the main article of criminal acts of embezzlement, it should be understood that there must be elements that are met as a criminal act of embezzlement, whether it is a subjective element or objective elements, in order for a legal event to enter criminal offense of embezzlement. From the provisions of Article 372 of the Criminal Code above, it can be concluded that the offense of embezzlement must meet the main elements namely: 1 . Subjective Elements Delik in the form of intentional Actors to embezzle something goods (can be goods or money) owned by others that can be understood from the formulation of words in the Law like the word: "deliberately", then next, 2. Delik objects consist of: 1) Whose element; 2 ) Elements are unlawful, 3) The element of an object; 4) Elements in whole or in part belong to others; and last 5) The element of the thing is present to him not for evil ${ }^{1}$. Investigators are required to be able to conduct an analysis of a legal event whether it is criminal acts of embezzlement. It must be fulfilled subjective elements and objective elements. The subjective element must be known is true there is intentional by the criminal (opzet), so that it will bear the facts that the perpetrators of embezzlement: want or intend to control an item (can be in the form of money also unlawfully), know or realize that what the criminal wants to master is a good or money, know and realize that the goods or money are partly or wholly belong to the person, know or acknowledge that the goods or money are present in the Perpetrator not for a crime ${ }^{2}$.

In the offense of embezzlement based on the perspective of criminal law doctrine related to the objective elements, it can be understood that: The perpetrator of the embezzlement should take possession of objects that belong to other people is unlawful. Points against law (wederrnechtelijktoeeigenen) is a must attach to the deed Controlling objects belonging to others, so it must also be proven in the future. Based on the opinion of Van Bemmelen and Van Hattum, the meaning of unlawfully is as "contrary to the propriety in social association ${ }^{3}$."

\footnotetext{
Adami chazawi, Kejahatan terhadap Harta Benda, Bayu Media Publishing,Malang,2006, Page 64.

2 Soenarto Soerodibroto, KUHP Dan KUHAP, Edisi $\mathrm{Ke}-5$, PT. Radja Grafindo Persada, Jakarta, 2006. Page 106.

3 Ibid, Page 223.
} 
So there is an extension of the meaning that against the law should not be interpreted against the Law or against the written Rule, but also can be interpreted against social ethics and social decency. On the other hand, the scope of the meaning of "an object" belonging to another person controlled by the perpetrator of the embezzlement is unlawful. According to its nature, it can be moved or can be called moving objects. However, as the evolution of the evil mode grows and the object of embezzlement grows, the notion of the object undergoes an expansion of meaning, that is not only limited to movable objects but also in it including money. Thus money is also included as the object of embezzlement of the Perpetrators of embezzlement.

Objects are controlled by the criminal, in whole or in part, belong to another person. This is implies that there must be a real direct relationship between the Destroyer and the object under his control. In connection with the foregoing description, an Investigator in this case the Police of the Republic of Indonesia (hereinafter written Investigator) shall conduct an analysis of whether a legal event may be qualified as an Embezzlement Act or not, whether all its elements can be fulfilled or not. Even at the stage of starting a good investigation by the Victim of Embezzlement or Perpetrators of Embezzlement. It must always be understood in causality based on evidence, facts and information of both parties either the Perpetrator or the Victim. ${ }^{4}$ Along with the passage of time and the development of the investigation of the case, the Investigator must be able to be a good Mediator, in an impartial objective sense and offer a solution that can benefit both parties, so the case does not have to go through formal processes and procedures through the stages of criminal law enforcement.

The settlement of cases through the Judicial Authority is often too formalistic and rigid and does not provide a sense of substantive justice among the perpetrators and Victims of crime. Based on that thought, it is needed settlement of a case or criminal case oriented restorative justice. The concept of restorative justice aims to realize the balance between Perpetrators

4 Bazemore, Gordon \& Lode Walgrave. 2005. Restorative Juvenile Justice: Repairing the Harm of Crime. Building Press. London. Page 5-8 and Victims of criminal acts. It is also capable of realizing the handling of criminal cases can run in a flexible, not rigid and not formalistic and can be resolved quickly so as to save time, cost and energy. So what is the current legal policy of the Police and the Prosecutor's Office within the application of Restorative Justice criminal act of embezzlement. ${ }^{5}$ And what factors are the obstacles to the implementation of Police and Prosecutorial Law Policies in the application of Restorative Justice to current fraud crimes?

\section{B. DISCUSSION}

1. Police law and prosecution policy in the application of Restorative justice criminal act of embezzlement

The settlement of criminal law of embezzlement in Indonesia today is still subjective and based solely on humanitarian considerations. The considerations taken are subjective, because there is no legal Acts in the form of legislation that explicitly regulates it. Therefore, the legal umbrella used only in the form of legal policy decision called discretion. The discretion taken is only way beyond the guidance of criminal justice system process. Thus, the settlement of criminal embezzlement cases at the investigation level by the Police is only a win-winning solution, and can not meet the legal certainty as required by formal criminal law enforcement.

Nevertheless, the application of discretion is able to provide a real sense of justice desired by the perpetrators and victims of criminal act of embezzlement, including theirfamilies' respective.

The legal basis for the discretion of the Police is the provision of Article 18, Paragraph (1) of Law Number 2 Year 2002 on the Police of the Republic of Indonesia. The Police Discretion taken in the application of the settlement of criminal misconduct cases is based on the desired legal, humanitarian and substantive legal benefits By Perpetrators and Victims of criminal act of embezzlement. The

lbid., 
application of Police Discretion as Investigator conducting an investigation on crime of embezzlement case is only done by Police Investigator, if indeed the parties, that is, the perpetrators and Victims of criminal act of embezzlement have made a deliberation to reconcile each other, and the Performer has done its responsibility to return the loss Material suffered by Victims of criminal act of embezzlement.

Police Discretion is a legal policy of the Police. It is used to realize the wishes of society in accordance with the dynamics of law that continues to grow in enforcement. Legal policy by the Police as Investigators in the criminal act of embezzlement is a concrete manifestation of the application of restorative justice, and it is a positive response to the implementation Progressive Law. ${ }^{6}$

Completion of criminal case of embezzlement at the level of investigation by Investigator Police is based on the application of discretion or legal policy of the Police. The essence is informal settlement, and it is outside the rules of the law enforcement process which is based on the Criminal Justice System, so that the Investigator Police was not willing and can not officially issue a Termination of Inquiry. However, the related parties, the perpetrators and victims of the criminal act of embezzlement, ignore the presence or absence of the Termination of Investigation Orders Letter. For the perpetrators and victims, the most important thing is the sense of justice, without having to face proceedings before the Court which is rambling, not efficient in terms of time, takes cost and effort. For the police as investigators, floated the file of the criminal act of embezzlement, without administrative clarity, ie discontinued its investigation by issuing a Termination of Investigation Order, and do not proceed to the Prosecutor's Office. Thus the file

2013. Dekonstruksi Dan Gerakan Pemikiran Hukum Progresif. Thafa Media. Yogyakarata. Page 27-30 is a file that status quo. The same thing happened at the Attorney level, the Prosecutor as the Public Prosecutor, in case of peace between the perpetrator and the victim, the case is not issued the Prosecution Cessation Decree Letter, but continued to be transferred to the Court.

Those situations are separate issue in law enforcement efforts, which is based on Progressive Law with the application of restorative justice. Hence, it is necessaryto change the Criminal Code and the Criminal Procedure Code, which is able to set any explicit reference to the crime that can be accomplished through a restorative approach. Besides, it is also needed some fundamental changes about several things, including: ${ }^{7}$

1) There is a need for a rule of law that explicitly regulates the legal force of the peace agreement between the Perpetrator and the Victim and the authority of each subsystem either inside or outside the criminal justice system (Police, Prosecutor, Judge, Customary Institution, and Community) to apply the approach Restorative justice.

2) Qualification of crimes that can be resolved by using such an approach and shall be clearly defined.

3) Harmonization of rules of law related to institutional, criminal law material and formal criminal law is absolutely necessary, so that the uncertainty of Law Enforcement can be reached. If these three things are met, the subjectivity of law enforcement authorities in applying restorative justice approach can be resolved.

2. Factors that impede the implementation of legal policies in the Police and Prosecutor's Office in applying the restorative justice criminal act of embezzlement

In general, it can be explained the obstacles to implement legal policy in

Ibid., 
the Police or at the Prosecutor Office in the application of restorative justice, involving 5 (five) main points or principal, they are: ${ }^{8}$

1) The substance of Law has not been accommodating the implementation of restorative justice completely.

2) Law enforcement authorities are still carrying out the Criminal Code provisions rigidly. Since they only understand and apply legal rules textually, and yet take into consideration the major role given by the legal culture and socio-religious aspects of society.

3) The absence of a regulation that regulates the provisions on the handling of cases of criminal acts of embezzlement through restorative justice approach.

4) The mindset of the law enforcement authorities are still dominated by the understanding of formal positivistic prioritizing legal procedures, and lacked the courage to apply the law enforcement progressively, and to keep the law enforcement conservative, rigid, formal and prefer the certainty of law, But distanced from more real, more qualified justice for the Perpetrators and Victims of crime.

5) Coordination between Law Enforcement Officials, to change the Paradigm of Law Enforcement Officials from a formal legal Positivistic approach to Restorative Justice is not yet fully feasible.

\section{Conclusion}

The legal policies in the Police and Prosecutor's Office in the application of restorative justice to current criminal law of embezzlement. The settlement of criminal law of embezzlement in Indonesia today is still subjective and based solely on humanitarian considerations. The considerations taken are subjective, because

8 Anthony Mason, 2012. Restorative Justice, Chandra Pratama. Jakarta. Page 11 there is no legal umbrella in the form of legislation that explicitly regulates it. Therefore, the legal umbrella used only in the form of legal policy decision called discretion. The discretion taken is only way beyond the guidance of criminal justice system process. Thus, the settlement of criminal embezzlement cases, at the investigation level by the Police Department, and at the prosecution level by the Prosecutor Office is in fact only a win-winning solution, and can not meet the legal certainty as required by formal criminal law enforcement.

Nevertheless, the application of discretion is able to provide a real sense of justice desired by the perpetrators and victims of criminal acts of embezzlement, including their respective.

The basis of the Police discretionary law is the provision of Article 18, Paragraph (1) of Law Number 2 Year 2002 on the Police of the Republic of Indonesia. Police Discretion taken in the application of settlement of criminal embezzlement case is based on the legal, humanitarian and substantive benefits, in which the perpetrators and victims of the embezzlement want to. The application of Police Discretion as Investigator conducting an investigation on crime of embezzlement case is only done by Police Investigator. If it is indeed the parties, the perpetrators and Victims of criminal act of embezzlement will make a deliberation to reconcile each other, and the Performer has done its responsibility to return the loss Material suffered by Victims of criminal act of embezzlement.

Factors that impede the implementation of legal policies in the Police and Prosecutor's Office in applying restorative justice to the current criminal act. Generally, it can be concluded the obstacles to the implement of legal policy either in the Police or at the Prosecutor's Office in the application of restorative justice, involving 5 (five) main points, namely: The substance of the law has not been accommodating the implementation of restorative justice completely. Law Enforcement Officials still carry out the stipulations of the Criminal Code and Criminal Procedure Code rigidly. The absence of a regulation that regulates the provisions on the handling of cases of criminal acts of embezzlement through restorative justice approach. The mindset of the 
Law Enforcement Officials is still dominated by positivistic understanding. Coordination between Law Enforcement Officials, to change the Paradigm of Law Enforcement Personnel from the Positivistic approach to Restorative Justice is not yet fully feasible.

In order the Government and the People's Legislative Assembly of the Republic of Indonesia in performing its functions as Legislator make changes to the provisions of Article 372 of the Criminal Code, explicitly and expressly and mentioned about the qualification of criminal offenses-crimes that can be resolved by applying restorative justice.

In order to make changes to the Criminal Procedure Code (KUHAP), which relate to the provision of Article 109, Paragraph (2), regarding the termination of investigation and the provisions of Article 140, Paragraph (2), Subparagraph (a), on termination of prosecution, it shall be explicitly stated that the Prosecutor may terminate the prosecution due to an outof-process settlement, whether in the form of a peace or agreement, between the offender and the victim of a crime. As long as the Criminal Code and Criminal Procedure Code have not been amended as referred to in points (1) and (2) above, in order to realize real and qualified justice, in the settlement of criminal cases of embezzlement, if between the Perpetrator and the Victims of crime have agreed to make peace, Police Investigators and Prosecutor Apparatus as the Prosecutor, able to provide legal breakthrough in the form of application of discretion, as a concrete manifestation of legal policy oriented to the realization of substantial justice.

\section{BIBLIOGRAPHY}

A. Z . Abidin dan Andi Hamzah. 2010. Hukum Pidana Indonesia . Yarsif Watampone. Jakarta.

2011. Hukum Pidana Indonesia, Yarsif Watampone. Jakarta.

Abdullah, H. Rozali dan Syamsir, 2002. Perkembangan Dan Keberadaan Peradilan. Nusa Media. Bandung.

Achmad Ali, 1990. Mengembara di Belantara Hukum, Lembaga Penerbitan. Jakarta.

2013. Restoratif Justice Suatu Pengembaraan . Ujung Pandang. Lembaga Penerbitan Universitas Hasanuddin. Ujung Pandang.

Achmad Ali dan Wiwie Heryani. 2012. Sosiologi Hukum. Kencana. Jakarta.

Ahmad Gunawan,BS, 2012. Menggagas Hukum Progresif Indonesia. Pustaka Pelajar. Semarang.

Aloysius Wisnubroto, 1999. Kebijakan Hukum Pidana Dalam Penanggulangan Penyalahgunaan Komputer. Universitas Atma Jaya. Yogyakarta.

Ambo Upe \& Damsid. 2010. Asas-Asas Multiple Researches, TiaraWacana. Yogyakarta.

Amir Syamsuddin. 2002. Integritas Penegak Hukum, Kompas, Jakarta, 2008. Integritas Penegakan Hukum Pidana. Kompas. Jakarta.

2009. Tinjauan Sosiologi Hukum. Kompas. Jakarta.

2010. Integritas Penegak Hukum, Kompas. Jakarta.

Andi Hamzah. 2003. Asas Asas Hukum Pidana. Rineka Cipta. Jakarta.

, 2014. Hukum Acara Pidana Edisi Revisi. Sinar Grafika. Jakarta.

Anthony Mason, 2012. Restorative Justice. Chandra Pratama. Jakarta. 
,Menguak Tabir Hukum, Jakarta, Chandra Pratama , 2002.

Apeldoorn, Van, 1958. Inleiding tot de Studie van Het Nederlandse Recht,Rotterdam,Noordhoff Koff,

2000. Inleiding tot de Studie van Het Nederlandse Recht, Ashage Publishing Company. Nederland.

Bagir Manan, 2010. Retorative Justice (Suatu Perkenalan), Dalam Refleksi Dinamika Hukum Rangkaian Pemikiran Dalam Dekade Terakhir. Perum Percetakan Negara RI. Jakarta.

Bambang Poernomo. 1995. Asas-asas Hukum Pidana. Ghalia Indonesia. Jakarta.

Barda Nawawi Arief. 1998. Kapita Selekta Hukum Pidana, Citra Aditya Bhakti. Bandung. , 1998. Beberapa Aspek Kebijakan Penegakan Dan Pengembangan Hukum Pidana, Suatu Telaah Kritis. Citra Aditya Bhakti. Bandung.

Balitbang HAM. 2006. Perspektif Hukum dan Hak Asasi Manusia. Balitbang HAM Departemen Hukum dan HAM RI. Jakarta.

Bazemore, G., \& Schiff, M. 2005. Juvenile Justice Reform And Restorative Justice. Building Press. London.

Bazemore, Gordon \& Lode Walgrave. 2005. Restorative Juvenile Justice: Repairing the Harm of Crime. Building Press. London.

Braithwaite John and Heather Strang. 2001. Restorative Justice and Civil Society, Galaway. London.

Djauhari, Politik Hukum Negara Kesejahteraan Indonesia,Semarang,Unissula Press,2008. 1999. Restorative Justice. Criminal Justice Press. New York.

Esmi Warassih. 2005. Pranata Hukum Sebuah Telaah Sosiologis. PT. Suryandaru. 2005.

Undang - Undang Dasar Republik Indonesia Tahun 1945.

Kitab Undang - Undang Hukum Pidana ( KUHP ) .

Kitab Undang - Undang Hukum Acara Pidana (KUHAP) .

Rancangan Undang - Undang Kitab Undang - Undang Hukum Pidana.

Rancangan Undang - Undang Kitab Undang-Undang Hukum Acara Pidana.

Undang - Undang Nomor : 16 Tahun 2004 Tentang Kejaksaan Republik

Indonesia.

Undang - Undang Nomor : 2 Tahun 2002 Tentang Kepolisian Negara Republik Indonesia

Undang - Undang Nomor: 14 Tahun 1985 Tentang Mahkamah Agung.

Undang-Undang Nomor: 48 Tahun 2009 Tentang Kekuasaan Kehakiman.

Peraturan Kepala Negara Republik Indonesia Kepolisian Nomor : 22 Tahun 2010 Tentang Susunan Organisasi Dan Tata Kerja Pada Tingkat Kepolisian Daerah .

Peraturan Kepala Kepolisian Negara Republik Indonesia Nomor : 23 Tahun 2010 Tentang Susunan Organisasi Dan Tata Kerja Pada Tingkat Kepolisian Resor .

Putusan Mahkamah Agung No: 2127 K/Pid/2001. 
Putusan Mahkamah Agung No: $15 \mathrm{~K} / \mathrm{Pid} / 2007$.

Dokumen A/Conf.169/6 pada Kongres Perserikatan Bangsa - Bangsa ke 9 Tahun 1995.

Laporan Kongres Perserikatan Bangsa - Bangsa Tentang "The Prevention Of Crime And The Treatment Of Offenders “;"International Penal Refor Conference "Tahun 1999 di London .

Kongres Perserikatan Bangsa - Bangsa ke - 10 Tahun 2000 , menghasilkan Deklarasi Wina : “ The EV Council Framework Decision-Mediation inCriminal Case. Economic and Social Council (ECOSOC) United Nations Resolution2002/12Basic principles on the use of restorative justice programmes in criminalmatters Indonesia.

Prayitno, Kuat Puji,"Restorative Justice Untuk Peradilan Di Indonesia

(Perspektif Yuridis Filosofis Dalam Penegakan Hukum In Concreto)", Jurnal Dinamika Hukum Vol. 12 No. 3 September 2012.

Asshiddiqie, Jimly," Pembangunan Hukum dan Penegakan Hukum di Indonesia, (makalah Disampaikan pada acara Seminar " MenyoalMoral Penegak Hukum" dalam rangka Lustrum XI FakultasHukum Universitas Gadjah Mada. 17 Februari 2006).

Rahardjo, Satjipto, "Rekonstruksi Pemikiran Hukum di Era Reformasi" ( makalah disampaikan dalam Seminar Nasional MenggugatPemikiran Positivisme di Era Reformasi, PDIH, UNDIP Semarang,22 Juli 2000).

Seminar Nasional Hukum Progresif I. Diselenggarak Fukultas Hum Universitas Diponegoro bekerja sama dengan Program Doktor IImu Hukum dan Fakultas Hukum Universitas Trisakti, Jakarta di Semarang, 15 Desember 2007).

http://www.restorativejustice.org/ Jecky Tengens, Pendekatan RestorativeJustice Dalam Sistem Peradilan Pidana Indonesia, http://www.hukumonline.com. Pendekatan Restorative Justice Dalam SistemPidana Indonesia ,

http://www.unodc.org/pdf/criminal-justice/06-56290-Ebook.pdf, UnitedNations Office on Drugs and Crime, Handbook on RestorativeJusticeProgrammes, New York United, 